\title{
Effect of Using Spot the Dictogloss to Students’ Listening Skill
}

\author{
Sabilla Sari Faradini ${ }^{1}$, Sri Sugiharti ${ }^{2}$, Eka Wilany $^{3}$ \\ English Education Department \\ University of Riau Kepulauan Batam \\ ssarifani@gmail.com¹, srisugihartiwismono@yahoo.com²,ekaluney@yahoo.co.id ${ }^{3}$
}

\begin{abstract}
This research was aimed to find out whether significant effect of using Spot the Dictogloss to students' listening skill at second grade students of SMAN 17 Batam in academic years 2015/2016. The research conducted experimental research in April 2016 and was held on second grade with the number of sample was 60 students of SMAN 17 Batam. The writer used cluster random sampling technique to determine class of the research. In this research, the writer conducted in two classes, XI IIS 1 and XI IIS. The experimental class was taught listening by using spot the dictogloss, whereas the control class was taught listening by using running dictation strategy. Data was collected by multiple choice test. The result of the research showed there was a significant difference of the students' achievement before conducted treatment which they had mean 40.5 for experimental class and 42.5 for control class. The average of the students' achievement after conducted treatment in experimental class was 55.33 and in control class was 48.33. Based on this finding, it is suggested that spot the dictogloss could be used by the teacher to improve students' listening skill.
\end{abstract}

Keywords: spot the dictogloss, listening skill

\section{INTRODUCTION}

In this research, the objective of the study is to find out the significant effect of using Spot the Dictogloss to students' listening skill at second grade students of SMAN 17 Batam in academic years 2015/2016. The students cannot understand the listening material is one of the students' difficulty. There are some ways to understand the students' difficulties in listening, one of it is we must indicate the some factors that become problem in listening. In a study that conduct by Bennui (2007:5) at Thaksin University showed factors that influencing English as a Second Language (ESL)/ English as a Foreign Language (EFL) students' listening performance are students factors, speaker factors, characteristics of the spoken language, classroom facilities and teaching method factors. 
In the learning activities, there are many techniques that is used to motivate and improve the students' listening skill. One of it is spot the dictogloss. Spot the dictogloss is a classroom dictation activity where students reconstruct a short text by listening and making the key word, which are then used as a base for reconstruct.

There were some identifications of the study in this research. Firstly, the students get difficult to understand the spoken English. Then, the students have a little vocabulary understanding. The third, students are difficult to understand the instructions or sentences that teacher said in English. The last is some teachers use conventional method to teach listening lesson. The study was limited to focus on the effect of using Spot the Dictogloss to students' listening skill at second grade students of SMAN 17 Batam academic years 2015/2016.

According to Arief and Adnan (2013:50), listening is considered as the language acquisition form. It means a new baby starts acquire a language by listen the voice in around of environment before starts to speak and learn the other skill, like read and write. Based on explanation above, the writer concluded that listening is paying attention activity to receive and understand what the speaker said before produce the other skills. In the other hand, listening becomes important in human language development.

According to Vasiljevic (2010:45), there are some advantages of Spot the Dictogloss, they are spot the dictogloss is effective for combine the individual and group learning activities, spot the dictogloss help students to develop their communicative competence, in the reconstruction stage help student to find the specific information and identify the communication purpose of the listening dictation then in the analysis and correction stage help students to identify the problem that student that student have with text comprehension, spot the dictogloss can help students to help recreate the text that have similar content with the original, spot the dictogloss is unique combining of teaching listening and assessment of the students' listening, in vocabulary preparation, students can recall the written form and its meaning of the word and phrases contain in the listening dictation, the reconstruction tasks in the spot the dictogloss can raise the students' understanding in rhetorical patterns of the target language, the group working in spot the dictogloss can help students to reduce their anxiety because they perform only in front of the small audience.

In this study, the writer used multiple choice test format. Multiple choice tests are fast, easy and economical to score. In fact, they can even be scored by machines objectively and more reliable than subjectively score tests. 


\section{METHODOLOGY}

The research method which was used in this study was experimental research. According to Sugiyono (2014:72), experimental research is a research method that used to find influencing a treatment to the other in controlled condition. This research called quantitative research. Sugiyono (2014:8) explained that quantitative research is a research which analyse the data by using statistic. The research conducted at SMAN 17 Batam. It is located at Kavling Bukit Seroja Dapur 12 Batam. The research had done from April to May 2016. In this research, there are two variables, they are independent variable (this variable is called variable $\mathrm{X}$. In this research, there are two independent variables, they are spot the dictogloss technique for experiment class and running dictation strategy for control class and dependent variable (the dependent variable of this research is students' listening skill. This variable is called variable $\mathrm{Y}$ ).

In this research, the population is the second grade students of SMAN 17 Batam. The total number of population is 201 students. The students are divided into six classes. Each class consist of more less 30 students. Sample of this research is 60 students of class XI IIS 1 (as experiment class) and XI IIS 2 (as control class) by considering the homogeneity between both classes.

Sampling technique is a technique to take the sample. In this research, the sampling technique is taken by cluster sampling. Sugiyono (2014:83) states that cluster sampling is used to choose sample if the object that will be researched is wide. Cluster sampling in which group (not individuals) are randomly selected. The writer used this sampling technique because it was difficult to regroup the group.

By flapping a coin, one of two groups would randomly choose as experimental group and the other as the control group. Then, number of all sample were 60 students; 30 students were in the experimental group and 30 students were in the control group. Dealing with the sample size of experimental research, 60 students were representative enough to be the sample of this research. 


\section{RESULTS}

\section{Test Instrument}

\section{Validity of the Test}

In this research, the writer counted validity by using product moment correlation formula:

$$
r_{X Y}=\frac{N \Sigma X Y-(\Sigma X)(\Sigma Y)}{\sqrt{\left[N \Sigma X^{2}-(\Sigma X)^{2}\right]\left[N \Sigma Y^{2}-(\Sigma Y)^{2}\right]}}
$$

The result test which is gotten ( $\mathrm{r}_{\mathrm{XY}}$ value) and then be adapted with $\mathrm{r}$ product moment formula with significant extent $\alpha=5 \%$, if $r_{X Y}>r$ table, so the item is valid, but if $r_{X Y}<r$ table, the item is invalid. Based on the table above, there were 20 questions were valid, they were $2,3,4,5,7,10,12,13,17,18,22,23,28,29,31,33,34,35,37$, 39 and 20 questions were invalid, they were 1, 6, 8, 9, 11, 14, 15, 16, 19, 20, 21, 24, 25, 26, 27, 30, 32, 36, 38, 40.

\section{Reliability of the Test}

In this research, the writer used Kuder-Richardson formula or called K-R-21 formula to measure the reliability of instrument in Arikunto (2009:103) as follow:

$$
r_{11}=\left(\frac{n}{n-1}\right)\left(1-\frac{M(n-M)}{n \cdot S^{2}}\right)
$$

The range of reliability measures in this research is highest reliability, because it is in average $0.80<\mathrm{r} 11<1.40$ or $0.80<0.8177<1.40$.

\section{Normality of the test}

In order to see the normality of the result of the test, the writer has to use a formula, in this research the writer use Chi-square formula in Riduan and Sunarto (2012:68) as follows: 


$$
x^{2}=\sum \frac{(f o-f e)^{2}}{f e}
$$

From that calculation, the writer found that the data normality pre-test of experiment class was normal, because $\mathrm{x}^{2}{ }_{\text {obtain }}<\mathrm{x}^{2}$ table or $9.65<11.070$. From that calculation, the writer found that the data normality pre-test of control class was normal, because $\mathrm{x}^{2}{ }_{\text {obtain }}<\mathrm{x}^{2}$ table or $10.85<11.070$.

From that calculation, the writer found that the data normality post-test of experiment class was normal, because $\mathrm{x}^{2}{ }_{\text {obtain }}<\mathrm{x}^{2}$ table or $10.4<11.070$. From that calculation, the writer found that the data normality post-test of control class was normal, because $\mathrm{x}_{\text {obtain }}^{2}<\mathrm{x}^{2}$ table or $9.6<11.070$.

\section{Homogeneity of the Test}

According to Sugiyono (2014:197) the formula of variance:

$$
\mathrm{F}=\frac{\text { Biggest } \text { Variance }}{\text { Smallest Variance }}
$$

Based on that calculation, the writer concluded that variance of pre-test in experimental class and control classes were homogeneity, because $\mathrm{f}_{\text {obtain }}<\mathrm{f}_{\text {table }}, 1.3505<$ 1.861. Based on that calculation, the writer concluded that variance of post-test in experimental class and control classes were homogeneity, because $\mathrm{f}_{\text {obtain }}<\mathrm{f}_{\text {table }}, 1.52848$ $<1.861$.

\section{T-test}

The calculation of t-test between mean score of pre-test and post-test of experimental and control class, the writer used formula in Arikunto (2010:354) as follow:

$$
\mathrm{t}=\frac{M_{X}-M_{Y}}{\sqrt{\left(\frac{\Sigma X^{2}+\Sigma Y^{2}}{N_{X}+N_{Y}-2}\right)-\left(\frac{1}{N_{X}}+\frac{1}{N_{Y}}\right)}}
$$


After getting $\mathrm{t}$-test result, then it would be consulted to the critical score of $\mathrm{t}$ table to check whether the difference is significant or not, for $\alpha=5 \%$ with df $30+30-2=$ 58 , it was found $t_{\text {table }} 2.002$, because of score $t_{\text {obtain }}>t_{\text {table, }} 3.578>2.002$, so it could be concluded that there was significance of different between the experimental and control group.

\section{DISCUSSION}

Below was the discussion of the dominant the effect of using spot the dictogloss to students' listening skill at second grade students of SMAN 17 Batam. As discussed in the previous chapter that this research consist two variables namely Spot the Dictogloss (X) as independent variable and Students Listening Skill (Y) as dependent variable. It has been mentioned that the result of the data was significant or not significant. This study is aimed investigated whether the use of Spot the Dictogloss can increase students' listening skill.

The result of calculation in post test showed that there was significant difference between experiment class and control class after receiving treatment. The value of $\mathrm{t}_{\text {obtain }}$ was 3.578 while the value of $t_{\text {table }}$ was 2.002 with level significant 0.05 at the degree of freedom $(30+30-2)$ was 58 . It showed that the value of $t_{\text {table }}<t_{\text {obtain }}, 2.002<3.578$. It means Alternative Hypothesis ( $\mathrm{Ha}$ ) was accepted with stated that there is significant difference of mean score between experimental class and control class and Null Hypothesis (Ho) was rejected with stated that there is no significant difference of mean score between experimental class and control class.

Based on the research the writer concluded that in spot the dictogloss, the students can get new vocabulary related to material, listen the audio text recording and collect their understanding and memory to make a reconstruction text. The collaborative reconstruction task can give the students opportunities to practice and use the vocabulary and their own language. In process to make reconstruction task, spot the dictogloss also give contribution in students' writing skill. Then, the average score of experimental group in pre-test was 40.5, while the average score of post test was 55.33. Then, the average of control group in pre-test was 42.5 , while the average score for post-test was 48.33. It shows that the score of the students who got treatment with spot the dictogloss was higher than the students who got treatment without spot the dictogloss technique. It was proved by the obtained score of ttest.The $\mathrm{t}$-test showed that $\mathrm{t}$-score, 3.578 was higher than $\mathrm{t}_{\text {table }}$ 2.002.It means that Ha was accepted and Ho was rejected.Since the t-score was higher than t-table, there was 
significance difference in the achievement between student in experimental class who were taught by using spot the dictogloss and students in control class who were taught by using without using spot the dictogloss. It means there is significant effect of using spot the dictogloss to students’ listening skill at second grade students of SMAN 17 Batam.

In this study, the writer would like to offer some suggestion for English teacher, students and next researcher in order to get better result, they are. The first, for teacher spot the dictogloss may become alternative technique to teaching listening skill. Teaching listening by using spot the dictogloss is a good innovation. It can stimulate the students' listening skill in listen the audio, memorize audio text and reconstruction it in their own language. Then, before teaching and learning process, the teacher should have prepared the technique well. For students, it will be very useful for the students to listen a kind of audio text to increase listening skill. Students should pay attention to the teacher when she or he gives the English lesson. Then, for the next researcher, they can make this study as their reference to conduct other research on the same field. The writer hopes that the next researchers can prepare everything as good as possible in doing research and can follow up the research.

\section{REFERENCES}

Arief, Eka J and Adnan, A. (2013). The use of dictogloss method in teaching listening a hortatory exposition text at senior high school. Journal of English Language Teaching, Vol. 2 No. 1, September 2013, Serie A. Padang: Universitas Padang.

Arikunto, Suharsimi. (2009). Prosedur penelitian suatu pendekatan praktik edisi revisi 2010. Jakarta: Rineka Cipta.

Bennui, P. (2007). A survey on first year students' opinions concerning courses of their low performance in listening in the English II course. Journal of Western Language, Humanities and Social Science, Vol. 1 No. 4, June 2007. Thailand: Thaksin University Songkhla.

Riduan and Sunarto. (2012). Pengantar statistika. Bandung: Alfabeta.

Sugiyono. (2014). Penelitian kualitatif dan kuantitatif. Bandung. Alfabeta.

Vasiljevic, Zorana. (2010). Dictogloss as an interactive method of teaching listening comprehension to L2 learners, Journal of English Language Teaching, Vol. 3 No. 1, March 2010. Japan: Bunkyo University. 